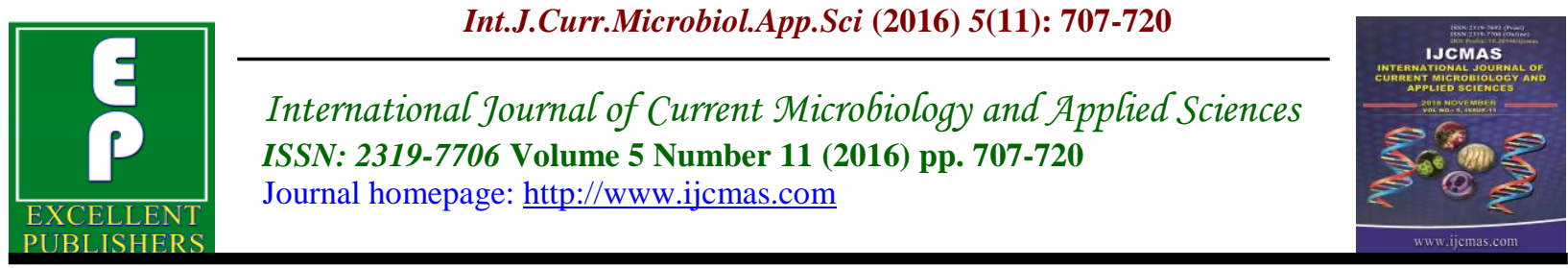

Original Research Article

http://dx.doi.org/10.20546/ijcmas.2016.511.082

\title{
Extraction of Phytochemicals from Local Selected Plants and their Antibacterial Role
}

\author{
Vijaykumar Biradar* \\ PG Studies \& Research Centre in Biotechnology, \\ Karnatak College, Bidar-585401, Karnataka state, India \\ *Corresponding author
}

\section{Keywords \\ Coriandrum sativum, \\ Mentha piperita, \\ Tridax procumbens, \\ Ocimum tenuiflorum \\ and Catheranthus \\ roseus, plant extracts, \\ TLC.}

Article Info

Accepted:

26 October 2016

Available Online:

10 November 2016

\section{A B S T R A C T}

The present study is carried out to assess the quality of five plants, Coriandrum sativum, Mentha piperita, Tridax procumbens, Ocimum tenuiflorum and Catheranthus roseus for their phytochemical composition as medicine \& their antibacterial effects. Phytochemicals of plants were obtained in aqueous \& ethanolic extracts. These extracts are screened for the detection of secondary metabolites. Among five selected plants, aqueous and ethanolic extracts of leaf \& stem have shown the presence of carbohydrates, alkaloids, steroids, glycosides, flavonoids, terpenoids and also oils \& fats. But carbohydrates in leaves of Mentha \& glycosides in leaves of Tridax of ethanolic extracts were found absent. Quinones were absent in both aqueous \& ethanolic extracts except in the aqueous extract of stem of Ocimum. Tannins were found in both the extracts, but showed negative result in ethanolic extract of leaf of Ocimum. Quinones were absent in ethanolic extraction leaf \& stems of all plants, but present only in the aqueous extract of stem of Ocimum. Tannins found in both aqueous \& ehanolic extractions of stem \& leaves of all plants except in the ethanolic leaf extract of Ocimum. Saponins found present in all but absent only in the ethanolic extract of stem of Tridax. Phenols found absent in aqueous extract of stems \& ethanolic extraction of leaves of all plant, whereas they are found in aqueous extraction of all leaves except Tridax. Antimicrobial activity has shown the highest zone of inhibition by leaf extract of Vinca roseus $(1.0 \mathrm{~cm})$ on E.coli bacteria.

\section{Introduction}

Since ancient times, people have been exploring large number of medicinal plants with disease curative properties. Peoples have applied herbs and its derivatives as therapeutic medicines (Newman, et al., 2003). Despite the abundance and advancement of synthetic drugs, a significant proportion of population of developing countries still depend on traditional medicines for their health care needs (Lesney, 2004; Okigbo \& Mmeka, 2006). Nearly $80 \%$ of the world's population relies on traditional medicines most of which involve the use of plant extracts (Schinor et al., 2007; Patel et al., 2011) and a large number of African and Asian populations use traditional medicines for their healthcare. 
In India, about $95 \%$ of the prescriptions are plant based in the traditional systems of Unani, Ayurveda, Homeopathy and Siddha (Satyavati \& Tandon, 1987). Around 80\% of products are of plant origin (Patwardhan \& Chorghade, 2004). Hence plants are the richest source of traditional \& modern medicines, food supplements, pharmaceutical intermediates etc. and relatively have lower incidences of adverse reactions, reduced cost is encouraging for both the consuming public \& consider plants medicines as alternatives to synthetic drugs (Nair et al., 2005; Sitara \& Hassan, 2011). The chemical substances produced by plants which have a definite physiological action on human body are generally known as phytochemicals. These are non-nutritive and act like shield against diseases associated with reduced risks of cancer, cardiovascular disease, diabetes, and other diseases associated with ageing (Zheng \& Quin, 2007). Nowadays in the developing countries, synthetic drugs are not only expensive and inadequate for the treatment of diseases but are also often with adulteration and side effects (Essawi \& Srour, 2000; Shariff, 2001) but medicinal plants are very ancient and only true natural medicines useful in several ways for the treatment of different diseases.

Only a small percentage of all plants species have been studied to some extent for the presence of primary \& secondary metabolites (Verpoorte et al., 2000) known as phytochemicals. These phytochemicals include both primary metabolites (carbohydrates, proteins, nucleotides etc.) essential for growth, development \& survival of the plant, and secondary metabolites (alkaloids, flavonoids, tannins, glycosides, steroids, saponins, resins, phenolic compound, lignins, stilbenes, betalains) required for specific functions like resistance against pests, diseases \& herbivores or attraction of pollinator etc (Zheng 2001; Cai et al., 2003). These secondary metabolites are not required by the human body for life sustenance, but they offer protection against pathogens (Beegum \& Devi, 2003; Kokate et al., 2006; Okigbo \& Igwe, 2007). Medicinal plants are increasingly gaining acceptance even among the literates, probably due to the increasing in efficacy of modern drugs used for the control of many infections as well as increase in resistance by several bacteria to various antibiotics \& the increasing cost of prescription drugs, for the maintenance of personal health. Hence the phytochemical study is an effective approach for discovering new drugs from medicinal plants (Duraipandiyan et al., 2006; Razia et al., 2013).

\section{Materials and Methods}

\section{Collection and processing of plant sps.}

Locally available five herb plant species were randomly selected for the extraction of secondary metabolites.

\section{Plants selected for the study}

Five local plants were selected such as Coriander (Coriandrum sativum), Pudeena (Mentha piperita), Tridax daisy (Tridax procumbens), Tulsi (Ocimum tenuiflorum) and Vinca roseus (Catharanthus roseus). They were brought fresh, early in the morning between 6-7am in and around Bidar city during the month of March \& April, 2015.

\section{Extraction of phytochemicals for qualitative tests}

The Plant parts such as leaves (L) \& stem (S) were washed with tap water to remove surface impurities, \& then rinsed with 
distilled water. All plant parts were made into chopped to $1-2 \mathrm{~cm}$, dried at $60^{\circ} \mathrm{C} \&$ made fine powder using grinder. Two methods (Blessy et al., 2012; Sanjay et al., 2013) followed for the extraction of phytochemicals qualitative analysis

Aqueous extract: 20gm of each powder sample was soaked \& squeezed in $200 \mathrm{ml}$ of distilled water for 30 minutes at $70^{\circ} \mathrm{C}$. These were filtered through Whatmann filter paper No.1 to get filtrates. These were stored in sterile bottles at $4^{\circ} \mathrm{C}$ for further use.

Ethanolic extract: $20 \mathrm{gm}$ of each powder sample was macerated in $95 \%$ ethanol for 72 hours at $27{ }^{\circ} \mathrm{C}$. These were filtered through Whatmann filter paper No.1 to get filtrates. These were stored in sterile bottles at $4^{\circ} \mathrm{C}$ for further use.

\section{Detection of phytochemicals by qualitative analysis}

Each of leaf \& stem extracts was screened for the presence of various phytochemicals by the following qualitative analysis.

Molisch's test for carbohydrates: In 3ml of extract, $2 \mathrm{ml}$ of Molisch's reagent was added, shaken, and then $2 \mathrm{ml}$ of concentrated $\mathrm{H}_{2} \mathrm{SO}_{4}$ was poured in it along the side of test tube. The violet ring at the interphase indicated the presence of carbohydrates

Mayer's test for alkaloids: In $2 \mathrm{ml}$ of extract, $2 \mathrm{ml}$ of concentrated $\mathrm{HCl} \&$ then 6 drops of Mayer's reagent were added. The pale yellow precipitate indicated the presence of alkaloids.

Ring test for steroids: In $0.5 \mathrm{ml}$ of the extract, $3 \mathrm{ml}$ of chloroform was added \& filtered. The filtrate was mixed with equal amount of concentrated $\mathrm{H}_{2} \mathrm{SO}_{4}$. The reddish brown colour ring with a slight greenish fluorescence indicated the presence of steroids.
Salkowski's test for glycosides: In $2 \mathrm{ml}$ of each extract, $2 \mathrm{ml}$ of chloroform, \& then $2 \mathrm{ml}$ of concentrated $\mathrm{H}_{2} \mathrm{SO}_{4}$ were added \& shaken gently. The reddish brown colour indicated the presence of steroids.

Lead acetate test for flavonoids: In $1 \mathrm{ml}$ of extract, $1 \mathrm{ml}$ of $10 \%$ lead acetate solution was added. The formation of a yellow precipitate indicated the presence of flavonoids.

Ring test for terpenoids: In $2 \mathrm{ml}$ of extract, $2 \mathrm{ml}$ of acetic acid \& $1 \mathrm{ml}$ concentrated $\mathrm{H}_{2} \mathrm{SO}_{4}$ was added. The blue green ring formation indicated the presence of terpenoid.

Concentrated $\mathrm{HCl}$ test for quinones: In $1 \mathrm{ml}$ of extract, $5 \mathrm{ml}$ of concentrated $\mathrm{HCl}$ was added. The yellow coloured precipitate indicated the presence of quinines.

Lead acetate test for tannins: In $2 \mathrm{ml}$ of extract, few drops of $1 \%$ Lead acetate was added. The yellowish precipitate indicated the presence of tannins.

Frothing test for saponins: In $2 \mathrm{ml}$ of extract, $2 \mathrm{ml}$ of distilled water was added \& shaken well. Frothing indicated the presence of saponins.

Ninhydrin test for proteins: In $2 \mathrm{ml}$ of extract, 4-5 drops of Ninhydrin reagent was added, mixed \& boiled in water bath for 23 minutes. A bluish-black colour indicated the presence of proteins.

Millon's test for amino acid: In $2 \mathrm{ml}$ extract, 4-5drops of Millon's reagent added \& heated gently. A reddish-brown colouration/ precipitate indicated the presence of tyrosine residue.

Ferric chloride test for phenol: In $1 \mathrm{ml}$ of 
extract, $1 \mathrm{ml} 3 \%$ ferric chloride added. The deep blue colour indicated the presence of phenol.

Fehling's test for reducing sugars: In $2 \mathrm{ml}$ of extract, $1 \mathrm{ml}$ of Fehling's reagent added \& the mixture was boiled in waterbath. The brickred colour indicated the presence of glycosides.

Boiling test for Phlobotannins: In $2 \mathrm{ml}$ of extract, $2 \mathrm{ml}$ of $1 \% \mathrm{HCl}$ was added \& the mixture boiled in waterbath. A red precipitate at the bottom indicated the presence of Phlobotannins.

Spot test for fixed oils and lipids: 2-3 drops of each extracts are passed between two filter papers \& allowed to dry. Appearance of an oil stain or a grease spot on the filter paper observed under sunlight indicated the presence of fixed oils.

\section{Extraction of phytochemicals from plants for TLC}

Ethanolic extraction method is a modified method of (Abdulrahman et al., 2004) used for the extraction of phytochemicals from plants. The fresh parts of the plant were dried in oven \& ground to fine powder by grinder. $10 \mathrm{gm}$ of each plant part was then macerated in $100 \mathrm{ml}$ of ethanol for 72 hours, then covered with aluminium foil $\&$ labeled. After 72 hours of extraction, each extract was filtered through Whatman's filter paper no.1. The filtrate was evaporated to dryness at room temperature \& stored at $5^{\circ} \mathrm{C}$ in refrigerator (Sanjay et al., 2013).

\section{Preparation of TLC plates \& loading of samples}

The glass plates $(20 \times 20 \mathrm{~cm})$ coated $(0.2-$ $0.3 \mathrm{~mm}$ thick) with silica gel $(30 \mathrm{gm} / 60 \mathrm{ml}$ distilled water) were dried at room temperature. The dried plates were activated at $100^{\circ} \mathrm{C}$ for 30 minutes in an oven \& cooled at room temperature. Each sample were separately spotted $1 \mathrm{~cm}$ above the edge of the plates by using capillary tubes. These spotted glass plates were placed in an air tight chromatography chamber containing $200 \mathrm{ml}$ of different solvent mixture/mobile phase for isolation of chemical compounds (Vidya et al., 2008). The developed chromatograms were air dried \& one of the TLC plate observed under UVtransilluminator for detection of flavonoids. Remaining each plate sprayed with different reagents (table 1) \& air dried for the detection of other metabolites.

\section{Calculation $\mathrm{Rf}$ for detection of phytochemicals}

The $\mathrm{R} f$ (=Retention factor) values were calculated for separated bands. $\mathrm{Rf}$ is the ratio of distance travelled by sample \& distance travelled by the solvent system.

$\mathrm{R} f=\frac{\text { Distance travel by solute }}{\text { Distance travel by solvent }}$

Methanolic extraction to assess
antimicrobial activity

The leaves \& stems washed thoroughly to remove surface dirt particle, dried in oven at $60^{\circ} \mathrm{C} \&$ powdered. 25gms of the plant material was kept in $100 \mathrm{ml}$ of methanol for 24 hours \& then boiled till the volume gets reduced to one-third. The crude extracts were obtained by filtration through Whatman filter no. 1 and stored at $4^{\circ} \mathrm{C}$ (Lin et al., 2004).

\section{Collection of pathogenic microbes}

Three pure culture of pathogenic bacteria, Escherichia coli, Staphylococcus aureus \& Pseudomonas sps., were collected from 
Azyme Bioscience Pvt. Ltd. Research Centre, Bangalore. They were mass cultured in nutrient broth, \& used for the study of antibacterial activity of plant extracts on them.

\section{Antibacterial study (Agar cup diffusion method)}

Antibacterial effect of methanolic leaf (L) and stem (S) extracts were determined by using cup diffusion method on nutrient agar medium (NAM) \& Muller Hinton agar (MHA) medium. 200 $\mu$ l of 24 hours of bacterial cultures were aseptically swabed with the help of cotton on the surface of gelled NAM \& MHA plates to develop culture lawns. A well of about $6.0 \mathrm{~mm}$ diameter made aseptically using cork borer in the medum. 50 $\mu$ l of each extract was poured into the wells. A well of negative control was made for extractant (solvent) \& positive control was made by placing antibiotic discs of ampicillin \& streptomycin on medium. Plates were left for 30 minutes for diffusion of extract into the medium \& then incubated at $37^{\circ} \mathrm{C}$ for $24 \mathrm{hrs}$. After incubation, the plates were observed for the zone of inhibition (ZI) of bacterial growth and the diameter of the inhibition zone were measured using geometrc scale.

\section{Results and Discussion}

Aqueous \& ethanolic extracts of leaves \& stems of all plants revealed the presence of secondary metabolites like carbohydrates, alkaloids, steroids, glycosides, flavonoids, terpenoids, quinones, tannins, saponins, proteins and amino acids, phenols, reducing sugars, phlobotannins and, oils \& fats. The aqueous extracts have shown the presence of most of secondary metabolites and these were confirmed by ethanolic extraction. However, some secondary metabolites extracted only with aqueous solvent \& some with ethanol solvent.
Aqueous extracts have shown more number of phytoconstituents (128), than ethanolic extracts (113) which is to be highlightened (tables $2 \& 3$ )because successive isolation of phytoconstituents from plant material is largely dependent on the type of solvent used in the extraction procedure. The traditional healers use primarily water as the solvent (Padmavathy \& Mekala, 2013) thus is a positive consideration that phytochemical screening, has shown aqueous extract is found to be more effective than ethanolic extract.

Among five selected plants both aqueous and ethanolic extracts of leaves \& stem shown the presence of phytoconstituents like carbohydrates, alkaloids, steroids, glycosides, flavonoids, terpenoids and, oils $\&$ fats. But absence of carbohydrates found in leaves of Mentha piperita \& glycosides in leaves of Tridax procumbens of ethanolic extractions. More specifically, the presence of Carbohydrates, Alkaloids, Steroids, Glycosides, Flavonoids, Terpenoids and oils $\&$ fats indicate energy source, antimicrobial $\&$ anti-diarrheal properties in these plants (Cowan et al., 1999; Kumar et al., 2010). Presence of Alkaloids has shown antimicrobial, anti-fungal, anti-tumour, cytotoxic, anti-plasmodial, anti-oxidant, anti-mutagenic, anti-genotoxic \& hallucinogenic properties. The earliest records of natural products were depicted on clay tablets in cuneiform from Mesopotamia (2600 B.C.) which documented oils from Cupressus sempervirens (Cypress) and Commiphora species which are still used today to treat coughs, colds and inflammation. Glycoside participates in the biosynthesis \& remodulation of glycans, mobilization of energy, defense, symbiosis, signaling, secondary plant metabolism \& metabolism of glycolipids (Panter, 2008). Glycoside was found to enhance cardiac conduction, thereby improving the strength 
of cardiac contractibility. Presence of Flavonoids in plants has revealed antiinflammatory, antioxidant, anticancer, antibacterial \& antiviral properties (Valsaraj et al., 1997; Hollman \& Katan, 1999; Harborne \& Williams, 2001). Presence of Terpenoids showed anti-inflammatory (Brunaton, 1999) \& hemolytic (Heinrich et al, 2004) properties. Plant essential oil \& fats extracts have been used for many thousand years in food preservation, pharmaceuticals, alternate medicine \& normal therapies (Reena et al., 2010). Quinones are found absent in both aqueous $\&$ ethanolic extracts except in the aqueous extract of stem of Ocimum tenuiflorum. Tannins found in both the extracts, but showed negative result in ethanolic extract of leaf of Ocimum tenuiflorum. Compared to the other plants, Quinones found absent in ethanolic extraction leaf \& stems of all plants, but present only in the aqueous extract of stem of Ocimum tenuiflorum. Quinones show a biological, pharmacological activity, and some of them show anti-tumoural activity. They embody some claims in herbal medicine. These applications include purgative, antimicrobial \& anti-parasitic, anti-tumour \& anti-cardiovascular disease. In 2004, the anti-malarial drug quinine isolated from the bark of Cinchona succirubra Pav. Tannins found present in both aqueous \& ehanolic extractions of stem \& leaves of all plants except in the ethanolic leaf extraction of Ocimum tenuiflorum. Tannins show anticarcinogenic, anti-mutagenic, anti-oxidative, anti-microbial properties, also exert other physiological effects such as to accelerate blood clotting, reduce blood pressure, decrease the serum lipid level \& modulate immunoresponses (Chung, et al., 1998). Saponins found present in all but absent only in the ethanolic extraction of stem of Tridax procumbens. Presence of saponins in leaf \& stem extracts of all plants except
Tridax plant indicates anti-diarrhael, antihelminthic, anticancer activities of these plants (Sutar et al., 2000; Padmawathy \& Mekala 2013). Proteins \& amino acids found in all plants except in the aqueous extraction of leaf, and ethanolic \& aqueous extractions of leaf \& stem respectively of Tridax procumbens. Phenols found absent in aqueous extract of stems \& ethanolic extraction of leaves of all plant, whereas they are found in aqueous extraction of all leaves except Tridax procumbens. Phenols acts as antioxidants also associated with the inhibition of atherosclerosis \& cancer (Martinez et al., 2000). Reducing sugars have shown positive test with aqueous extraction of both leaves \& stems of all plants except in Mentha piperita \& Tridax procumbens. Whereas ethanolic extractions of leaves of coriandrum, Tridax \& Vinca, and stems of Mentha, Tridax, Ocimum \& Vinca are shown positive results \& negatives in others. Phlobotannins have shown positive test with aqueous extraction of stems of all plants and leaves of only Mentha \& Ocimum. Whereas, ethanolic extractions of both leaves \& stem of all plants shown negative results except in the stem extraction of Ocimum.

In addition to the biologically active plantderived natural products, many other plant derived natural products have served as "lead compounds" for the design, synthesis and development of novel drug compounds (Kinghorn \& Balandrin, 1993; Newman et al., 2003; Lesney, 2004). In this context, some herb derived natural products have been modified slightly to render them more effective or less toxic in order to produce the so called "semi-synthetic drugs" (Kinghorn \& Balandrin, 1993; Kong et al., 2003). As an example of this type of strategy, aspirin was developed in 1953 through structural modification of salicylic acid which was identified as the active ingredient in a 
number of plants known for their pain relieving qualities (Kong et al., 2003; Lesney, 2004).

\section{Secondary metabolites detected by TLC}

TLC of leaves \& stem extracts of 5 plants revealed different compounds in different parts of the each plant. Detected compounds on TLC for alkaloids in leaves of Coriander, Pudeena, Tridax, Tulsi \& Vinca are 3, 5, 5, 4 \& 3 respectively. Similarly, stem has 3, 3, 3,
4 \& 3 respectively. However, these compounds are different in leaves \& stem extracts. This indicates various plant parts have different consequents of phytochemicals. Similarly, the same results have been obtained for Flavonoids, Saponins, and Terpenoids.

TLC results of leaf \& stem extracts for biohemicals of all selected plants shown the $\mathrm{R} f$ values as mentioned in table $4,5,6,7 \&$ Figs.1,2,3,4.

Table.1 Different solvent systems \& reagents used for TLC

\begin{tabular}{|l|l|c|l|}
\hline $\begin{array}{l}\text { Secondary } \\
\text { Metabolites }\end{array}$ & \multicolumn{1}{|c|}{ Solvent systems } & \multicolumn{1}{|c|}{ Ratio } & \multicolumn{1}{c|}{$\begin{array}{c}\text { Spraying } \\
\text { reagents }\end{array}$} \\
\hline Alkaloid & Methanol: ammonium hydroxide & $(17: 3)$ & Mayer's reagent \\
\hline Flavonoid & n-butanol: glacial acetic acid: water & $(4: 1: 5)$ & UV- Light \\
\hline Saponin & Chloroform: glacial acetic acid: methanol & $(6: 2: 1: 1)$ & Iodine vapours \\
\hline Terpenoid & Benzene : ethyl acetate & $(5: 95)$ & $10 \% \mathrm{H}_{2} \mathrm{So}_{4}$ \\
\hline
\end{tabular}

Table.2 Phytochemicals detected in aqueous extracts of leaves \& stems.

\begin{tabular}{|c|l|l|l|l|l|l|l|l|l|l|l|l|l|l|}
\hline S.No. & Phytochemicals & Test performed & \multicolumn{7}{|c|}{ Aqueous extracts } \\
\cline { 4 - 9 } & & & & \multicolumn{3}{|c|}{ Leaves } & \multicolumn{7}{|c|}{ Stems } \\
\cline { 3 - 9 } & & & L1 & L2 & L3 & L4 & L5 & S1 & S2 & S3 & S4 & S5 \\
\hline a) & Carbohydrates & Molisch's Test & + & + & + & + & + & + & + & + & + & + \\
b) & Alkaloids & Mayer's Test & + & + & + & + & + & + & + & + & + & + \\
c) & Steroids & Ring Test & + & + & + & + & + & + & + & + & + & + \\
d) & Glycosides & Salkowski's Test & + & + & + & + & + & + & + & + & + & + \\
e) & Flavonoids & Lead acetate Test & + & + & + & + & + & + & + & + & + & + \\
f) & Terpenoids & Ring Test & + & + & + & + & + & + & + & + & + & + \\
g) & Quinones & Conc.HCl Test & - & - & - & - & - & - & - & - & + & - \\
h) & Tannins & Lead acetate Test & + & + & + & + & + & + & + & + & + & + & + & + \\
i) & Saponins & Froathing Test & + & + & + & + & + & + & + & + & + & + \\
j) & Proteins \& & Ninhydrin Test, & + & + & - & + & + & + & + & + & + & + \\
& amino acids & Millon's Test & + & + & - & + & + & + & + & + & + & + \\
k) & Phenols & Ferric chloride Test & + & + & - & + & + & - & - & - & - & - \\
l) & Reducing sugars & Fehling's Test & + & - & - & + & + & + & + & + & + & + \\
m) & Phlobotannins & Boiling Test & - & + & - & + & - & + & + & + & + & + \\
n) & Oils \& Fats & Spot Test & + & + & + & + & + & + & + & + & + & + \\
\hline
\end{tabular}

(+) present, (-) absent 
Table.3 Phytochemicals detected in ethanolic extracts of leaves \& stem.

\begin{tabular}{|c|c|c|c|c|c|c|c|c|c|c|c|c|}
\hline \multirow[t]{3}{*}{ S.No } & \multirow[t]{3}{*}{ Phytochemicals } & \multirow[t]{3}{*}{ Test performed } & \multicolumn{10}{|c|}{ Ethanolic extracts } \\
\hline & & & \multicolumn{5}{|c|}{ LEAF SAMPLES } & \multicolumn{5}{|c|}{ STEM SAMPLES } \\
\hline & & & L1 & L2 & $\mathbf{L 3}$ & L4 & L5 & S1 & S2 & S3 & S4 & S5 \\
\hline a) & Carbohyderates & Molisch's Test & + & - & + & + & + & + & + & + & + & + \\
\hline b) & Alkaloids & Mayer's Test & + & + & + & + & + & + & + & + & + & + \\
\hline c) & Steroids & Ring Test & + & + & + & + & + & + & + & + & + & + \\
\hline d) & Glycosides & Salkowski's Test & + & + & - & + & + & + & + & + & + & + \\
\hline e) & Flavonoids & Leadacetate Test & + & + & + & + & + & + & + & + & + & + \\
\hline f) & Terpenoids & Ring Test & + & + & + & + & + & + & + & + & + & + \\
\hline g) & Quinones & Conc.HCl Test & - & - & - & - & - & - & - & - & - & - \\
\hline h) & Tannins & Leadacetate Test & + & + & + & - & + & + & + & + & + & + \\
\hline i) & Saponins & Froathing Test & + & + & + & + & + & + & + & - & + & + \\
\hline j) & Proteins \& & Ninhydrin Test, & + & + & + & + & + & + & + & + & + & + \\
\hline & amino acids & Millon's Test & + & + & - & + & + & + & + & + & + & + \\
\hline k) & Phenols & Ferric chloride Test & - & - & - & - & - & - & - & - & - & - \\
\hline 1) & Reducing sugars & Fehlings Test & + & - & + & - & + & - & + & + & + & + \\
\hline $\mathrm{m})$ & Phlobotannins & Boiling Test & - & - & - & - & - & - & - & - & + & - \\
\hline n) & Oils \& Fats & Spot Test & + & + & + & + & + & + & + & + & + & + \\
\hline
\end{tabular}

(+) present, (-) absent

Table.4 Rf values detected for identification of alkaloids

\begin{tabular}{|l|c|l|c|c|}
\hline \multicolumn{1}{|c|}{ Sample } & Plant part & \multicolumn{1}{c|}{ R $\boldsymbol{f}$ value } & Plant part & \multicolumn{1}{c|}{ Rf value } \\
\hline Coriander & L1 & $0.24,0.76,0.84$ & S1 & $0.88,0.94,0.99$ \\
\hline Pudeena & L2 & $0.16,0.39,0.46,0.52,0.59$ & S2 & $0.70,0.83,0.94$ \\
\hline Tridax & L3 & $0.16,0.37,0.47,0.54,0.59$ & S3 & $0.74,0.83,0.90$ \\
\hline Tulsi & L4 & $0.13,0.26,0.33,0.44$ & S4 & $0.20,0.66,0.83,0.91$ \\
\hline Vinca & L5 & $0.27,0.34,0.84$ & S5 & $0.68,0.86,0.93$ \\
\hline
\end{tabular}

Table.5 Rf values detected for identification of flavonoids.

\begin{tabular}{|l|c|l|c|l|}
\hline Sample & Plant part & $\mathbf{R} \boldsymbol{f}$ value & Plant part & $\mathbf{R} \boldsymbol{f}$ value \\
\hline Coriander & L1 & 0.91 & S1 & $0.15,0.93,0.98$ \\
\hline Pudeena & L2 & $0.95,0.94$ & S2 & $0.56,0.89,0.93$ \\
\hline Tridax & L3 & $0.91,0.86$ & S3 & $0.73,0.86,0.91$ \\
\hline Tulsi & L4 & $0.95,0.99$ & S4 & $0.95,0.99$ \\
\hline Vinca & L5 & $0.28,0.65,0.90$ & S5 & $0.21,0.41,0.58,0.92,0.94$ \\
\hline
\end{tabular}

Table.6 Rf values detected for identification of saponins.

\begin{tabular}{|l|c|l|c|l|}
\hline Sample & Plant part & $\mathbf{R} \boldsymbol{f}$ value & Plant part & $\mathbf{R} \boldsymbol{f}$ value \\
\hline Coriander & L1 & $0.89,0.99$ & S1 & $0.65,0.93$ \\
\hline Pudeena & L2 & $0.62,0.90$ & S2 & $0.84,0.88,0.89$ \\
\hline Tridax & L3 & $0.10,0.31,0.83$ & S3 & $0.28,0.81$ \\
\hline Tulsi & L4 & $0.15,0.5,0.80$ & S4 & $0.84,0.88,0.95$ \\
\hline Vinca & L5 & $0.16,0.48,0.6,0.9$ & S5 & $0.85,0,86,0.93$ \\
\hline
\end{tabular}


Table.7 Rf values detected for identification of terpenoids.

\begin{tabular}{|l|c|l|c|c|}
\hline Sample & $\begin{array}{c}\text { Plant } \\
\text { part }\end{array}$ & \multicolumn{1}{|c|}{ Rf value } & $\begin{array}{r}\text { Plant } \\
\text { part }\end{array}$ & \multicolumn{1}{c|}{ R $f$ value } \\
\hline Coriander & L1 & $0.04,0.06,0.11,0.70,0.81,0.96$ & S1 & $0.07,0.91,0.96$ \\
\hline Pudeena & L2 & $0.03,0.05,0.09,0.24,0.78,0.85,0.93$ & S2 & $0.08,0.90,0.99$ \\
\hline Tridax & L3 & $0.03,0.06,0.22,0.36,0.76,0.85,0.95$ & S3 & $0.06,0.28,0.90,0.98$ \\
\hline Tulsi & L4 & $0.04,0.07,0.08,0.27,0.76,0.86,0.94$ & S4 & $0.31,0.92,0.98$ \\
\hline Vinca & L5 & $0.04,0.08,0.11,0.15,0.56,0.88,0.96$ & S5 & $0.06,0.15,0.91,0.96$ \\
\hline
\end{tabular}

L-leaf, S-stem.

Table.8 Growth inhibition $(\mathrm{mm})$ of three bacteria by leaf extracts \& comparison with positive and negative controls on NAM \& MHA

\begin{tabular}{|l|l|l|l|l|l|l|l|l|l|l|l|l|l|l|l|l|l|l|}
\hline Bacteria & \multicolumn{4}{|c|}{ E.coli } & \multicolumn{4}{c|}{ Staphylococcus aureus } & \multicolumn{4}{c|}{ Pseudomonas } \\
\hline Media & \multicolumn{3}{|c|}{ NAM } & \multicolumn{3}{c|}{ MHA } & \multicolumn{3}{c|}{ NAM } & \multicolumn{3}{c|}{ MHA } & \multicolumn{3}{c|}{ NAM } & \multicolumn{3}{c|}{ MHA } \\
\hline Hours & $\mathbf{2 4}$ & $\mathbf{4 8}$ & $\mathbf{7 2}$ & $\mathbf{2 4}$ & $\mathbf{4 8}$ & $\mathbf{7 2}$ & $\mathbf{2 4}$ & $\mathbf{4 8}$ & $\mathbf{7 2}$ & $\mathbf{2 4}$ & $\mathbf{4 8}$ & $\mathbf{7 2}$ & $\mathbf{2 4}$ & $\mathbf{4 8}$ & $\mathbf{7 2}$ & $\mathbf{2 4}$ & $\mathbf{4 8}$ & $\mathbf{7 2}$ \\
\hline L1 & 0.2 & 0.3 & 0.5 & 0.2 & 0.3 & 0.4 & 0.0 & 0.0 & 0.0 & 0.3 & 0.5 & 0.7 & 0.3 & 0.4 & 0.4 & 0.2 & 0.4 & 0.6 \\
\hline L2 & 0.2 & 0.3 & 0.4 & 0.1 & 0.3 & 0.4 & 0.0 & 0.0 & 0.0 & 0.2 & 0.5 & 0.6 & 0.2 & 0.3 & 0.4 & 0.2 & 0.3 & 0.3 \\
\hline L3 & 0.1 & 0.3 & 0.4 & 0.1 & 0.3 & 0.4 & 0.0 & 0.0 & 0.0 & 0.1 & 0.2 & 0.3 & 0.2 & 0.3 & 0.4 & 0.2 & 0.3 & 0.3 \\
\hline L4 & 0.2 & 0.4 & 0.5 & 0.1 & 0.2 & 0.3 & 0.0 & 0.0 & 0.0 & 0.4 & 0.5 & 0.7 & 0.2 & 0.3 & 0.4 & 0.2 & 0.3 & 0.3 \\
\hline L5 & 0.4 & 0.7 & 1.0 & 0.2 & 0.4 & 0.5 & 0.0 & 0.0 & 0.0 & 0.2 & 0.4 & 0.7 & 0.4 & 0.5 & 0.5 & 0.2 & 0.3 & 0.3 \\
\hline Methanol $^{-}$ & - & - & - & - & - & - & - & - & - & - & - & - & - & - & - & - & - & - \\
\hline Amp $^{r}+$ & 0.8 & 1.0 & 1.2 & 0.2 & 0.5 & 0.8 & 0.4 & 0.6 & 0.8 & 0.9 & 1.3 & 1.5 & 0.6 & 0.8 & 0.8 & 0.5 & 0.7 & 0.9 \\
\hline Strep $^{r}+$ & 1.2 & 1.4 & 1.6 & 0.8 & 1.1 & 1.6 & 0.9 & 1.1 & 1.3 & 0.8 & 1.0 & 1.4 & 0.8 & 1.0 & 1.1 & 1.2 & 1.3 & 1.3 \\
\hline
\end{tabular}

Table.9 Growth inhibiton (in $\mathrm{mm}$ ) of three bacteria by stem extracts \& comparison with positive and negative controls on NAM \& MHA

\begin{tabular}{|l|l|l|l|l|l|l|l|l|l|l|l|l|l|l|l|l|l|l|l|}
\hline Bacteria & \multicolumn{4}{|c|}{ E.coli } & \multicolumn{4}{c|}{ Staphylococcus aureus } & \multicolumn{4}{c|}{ Pseudomonas } \\
\hline Media & \multicolumn{3}{|c|}{ NAM } & \multicolumn{3}{|c|}{ MHA } & \multicolumn{3}{c|}{ NAM } & \multicolumn{3}{c|}{ MHA } & \multicolumn{3}{c|}{ NAM } & \multicolumn{3}{c|}{ MHA } \\
\hline Hours & $\mathbf{2 4}$ & $\mathbf{4 8}$ & $\mathbf{7 2}$ & $\mathbf{2 4}$ & $\mathbf{4 8}$ & $\mathbf{7 2}$ & $\mathbf{2 4}$ & $\mathbf{4 8}$ & $\mathbf{7 2}$ & $\mathbf{2 4}$ & $\mathbf{4 8}$ & $\mathbf{7 2}$ & $\mathbf{2 4}$ & $\mathbf{4 8}$ & $\mathbf{7 2}$ & $\mathbf{2 4}$ & $\mathbf{4 8}$ & $\mathbf{7 2}$ \\
\hline S1 & 0.1 & 0.2 & 0.3 & 0.1 & 0.2 & 0.3 & 0.0 & 0.0 & 0.0 & 0.0 & 0.1 & 0.1 & 0.2 & 0.3 & 0.3 & 0.2 & 0.2 & 0.2 \\
\hline S2 & 0.0 & 0.1 & 0.1 & 0.1 & 0.2 & 0.2 & 0.0 & 0.0 & 0.0 & 0.0 & 0.1 & 0.1 & 0.2 & 0.3 & 0.3 & 0.2 & 0.2 & 0.2 \\
\hline S3 & 0.1 & 0.3 & 0.4 & 0.2 & 0.3 & 0.4 & 0.0 & 0.0 & 0.0 & 0.2 & 0.2 & 0.2 & 0.2 & 0.3 & 0.4 & 0.1 & 0.3 & 0.4 \\
\hline S4 & 0.2 & 0.3 & 0.3 & 0.0 & 0.1 & 0.1 & 0.0 & 0.0 & 0.0 & 0.1 & 0.3 & 0.4 & 0.2 & 0.3 & 0.4 & 0.2 & 0.3 & 0.4 \\
\hline S5 & 0.1 & 0.2 & 0.3 & 0.1 & 0.2 & 0.4 & 0.0 & 0.0 & 0.0 & 0.0 & 0.0 & 0.0 & 0.0 & 0.1 & 0.3 & 0.2 & 0.3 & 0.3 \\
\hline Methanol $^{-}$ & - & - & - & - & - & - & - & - & - & - & - & - & - & - & - & - & - & - \\
\hline Amp $^{r}+$ & 0.5 & 0.5 & 0.6 & 1.5 & 1.6 & 1.8 & 1.1 & 1.3 & 1.5 & 1.6 & 1.8 & 1.9 & 0.4 & 0.6 & 0.7 & 0.7 & 0.9 & 1.1 \\
\hline Strep $^{r}+$ & 0.8 & 0.9 & 1.3 & 1.4 & 1.6 & 1.8 & 0.8 & 1.2 & 1.5 & 1.2 & 1.6 & 1.7 & 0.9 & 1.2 & 1.7 & 0.4 & 0.5 & 0.8 \\
\hline
\end{tabular}



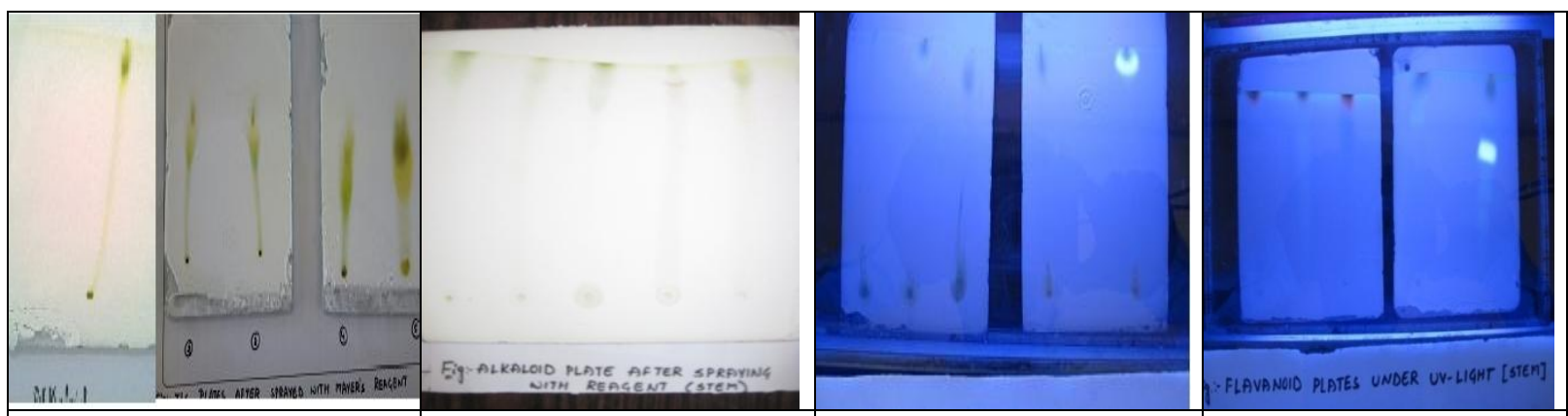

Fig.1a:Alkaloids in leaves Fig. $1 b$ :
extract extract leaves extract
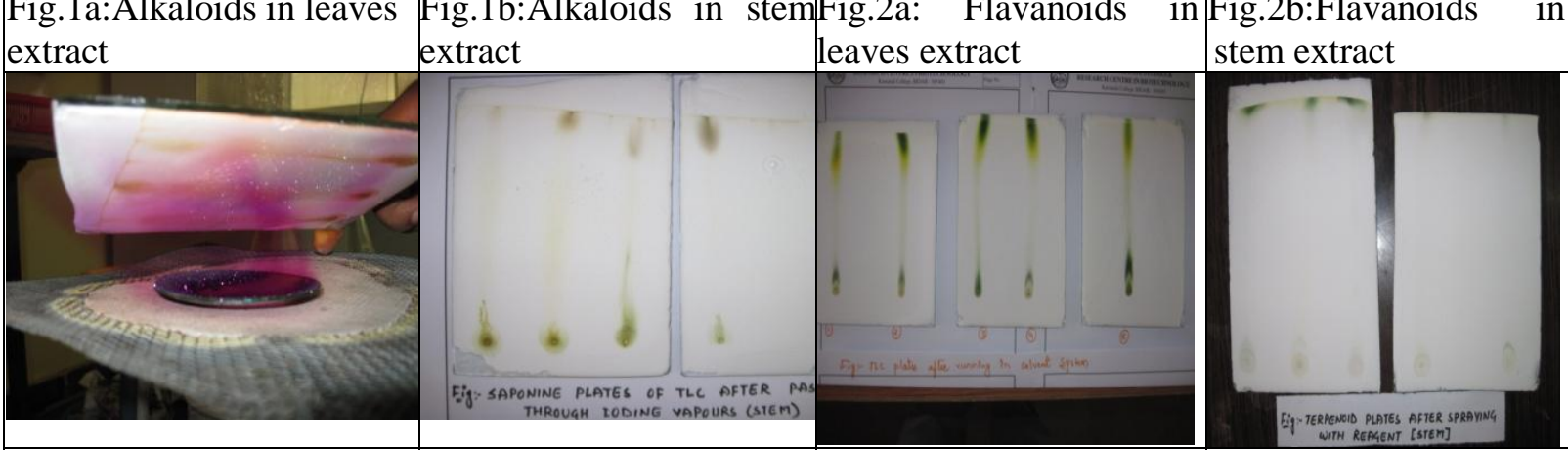

Fig.3a: Saponins in leaves Fig.3b:Saponins in stemFig.4a:Terpenoids extract extract leaves extract

in Fig.4b:Terpenoids in stem extract

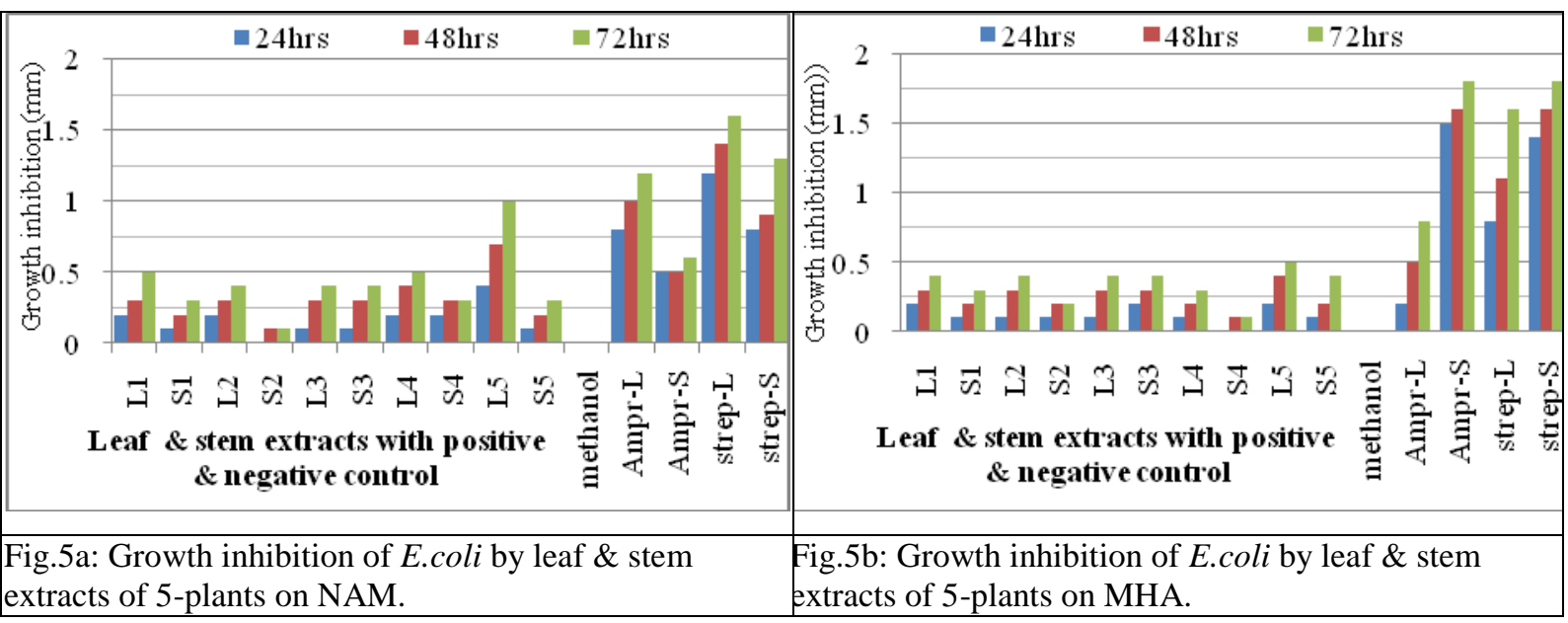

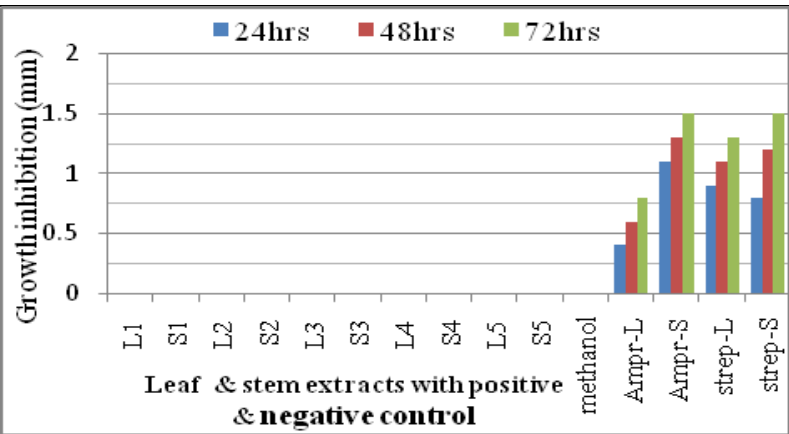

Fig.6a: Growth inhibition of S.aureus by leaf \& stem extracts of 5-plants on NAM.

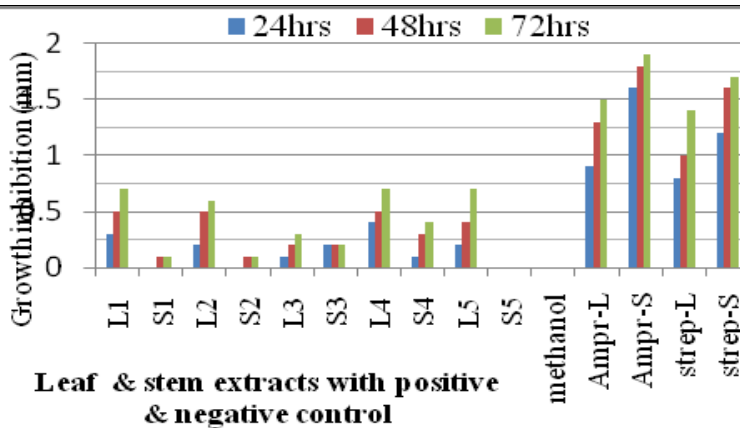

Fig.6b: Growth inhibition of S.aureus by leaf \& stem extracts of 5-plants on MHA. 


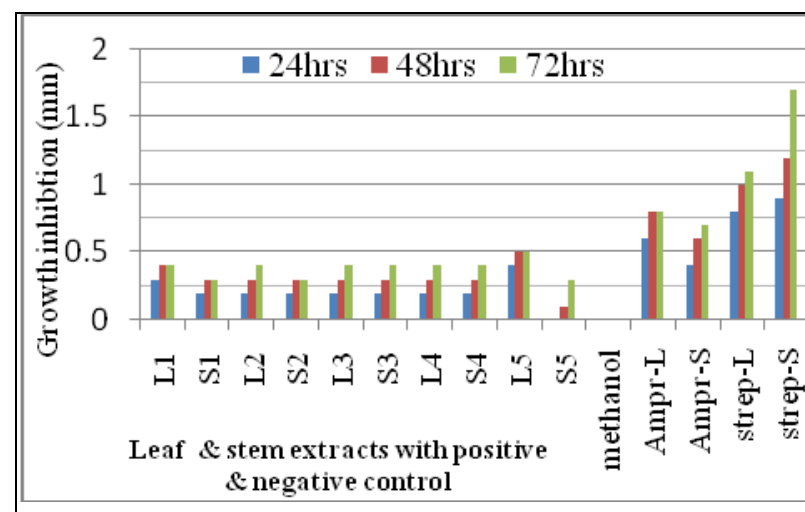

Fig.7a: Growth inhibition of Pseudomonas sps. by leaf $\&$ stem extracts of 5-plants on NAM.

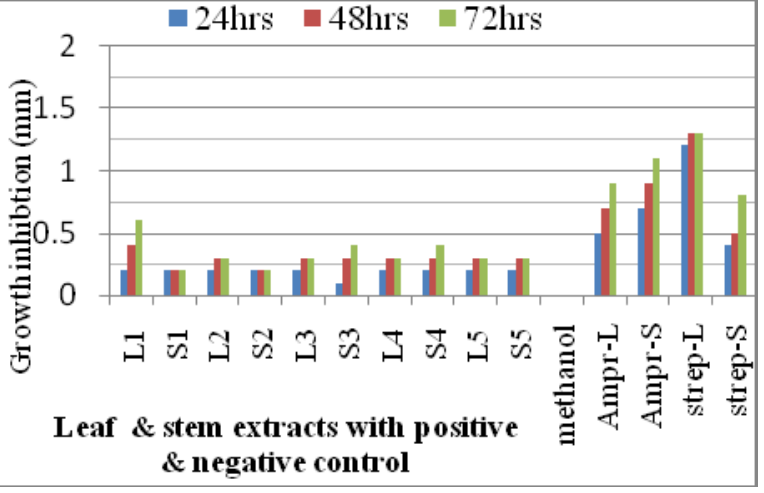

Fig.7b: Growth inhibition of Pseudomonas sps. by leaf \& stem extracts of 5-plants on MHA.

\section{Antibacterial effects of various extracts}

\section{Effects on E.coli (figs.5a\&b)}

The methanolic extracts of all plants have shown antibacterial effects on the growth of the cultures of E.coli in both NAM \& MHA. Further, the antibiotic effect of leaf extract has more than extracts of stem. In addition, it was also found that their effects with all extracts found more on NAM than on MHA. Whereas, its results were vice-versa with both +ve controls.

Higher effect on NAM by plant extracts than on MHA may be due to higher diffusion rate of extract into the NAM, than in MHA as the solid disc of +ve control has variation with these effects. The antibiotic effect of all extracts is not because of individual secondary metabolites but is the combined effect of all metabolites, as mentioned in tables $8 \& 9$.

\section{Effects on Staphylococcus aureus (figs.6a\&b)}

All plant extracts have shown antibacterial effect with the bacterial culture on MHA except with the extract of $S_{5}$. Whereas, these bacteria not grown on the NAM.
However, both +ve controls have significant antimicrobial effect with the cultures on both MHA \& NAM.

The plant extracts showed higher diffusion in MHA \& exhibited growth inhibition, but NAM might not supported for the multiplication of bacteria, hence zone of inhibition was not found on it. Significant zone of growth inhibition was observed with +ve control only on MHA as it was seen in previous results with E.coli.

\section{Effects on Pseudomonas sps. (Figs.7a \& b)}

All plant extracts have shown antibacterial effect with the cultures of pseudomonas sps.on both NAM \& MHA. Further, the antibiotic effect of leaf extract is more than extracts of stem. In addition, it was also found that the zone of growth inhibition was found more on NAM than MHA. Whereas, significant growth inhibition was found with streptomycin but not with ampicillin control. Higher effect on NAM by plant extracts than on MHA may be due to diffusion rate of extract into the NAM may be less than in MHA, as the solid disc of +ve control has no significant variation with these effects.

Thus, selected plant sps are potentially good source of traditional medicines \& 
therapeutics. Presence of bioactive compounds like Alkaloids, Steroids, Glycosides, Flavonoids, Terpenoids, Quinones, Tannins, Saponins, Phenols, \& Phlobotannins in leaves \& stems of five plants can be used for the treatment of different ailments like Malaria, Diarrhoea, Skin burn, Antimicrobial agents etc. Antimicrobial activity showed the highest zone of growth inhibition by leaf extract of Vinca roseus $(1.0 \mathrm{~cm})$ on E.coli bacteria.

\section{References}

Abdulrahman, F., Inyang, S.I., Abbah, J., Binda, L., Amos, S.,Gamaniel, K. 2004. Effect of aqueous leaf extracts of Irvingia gabonesis on gastrointestinal tracts of rodents. India J. Exp. Biol. 42, 787-791.

Beegum, B.N.R., Devi, T.G. 2003. Antibacterial activity of selected sea weeds from Kovalam South West coast of India. Asian J. Microbiol Biotech. Env. Sci. 5(3), 319-322.

Blessy, B., Mathew, S., Suresh, K. J., Archana, T. 2012. Phytochemical analysis of citrus limonium pulp and peel. Int. J. Pharmacy \& Pharmaceutical Sci.4(2),269-371.

Bruneton, J. 1999. Pharmacognosy, Phytochemistry \& Medicinal plants. Publisher: Lavoisier; 2nd edition, Intercept Ltd. England, UK. 1136 pages.

Cai, Y.Z., Sun, M., Corke, H. 2003. Antioxidant activity of betalains from plants of the Amaranthaceae. J. Agric. Food Chem. 51(8), 2288-2294.

Chung, K.T. 1998. Department of Microbiology \& Molecular cell sciences university of Memphis, TN 38152, USA. 38(6), 421-64.

Cowann, M.M. 1999. Plant products as antimicrobial agents. Clinical microbiology Reviews. 12(4), 564-582.
Duraipandiyan, V.M., Ayyanar, S., Ignacimuthu 2006. Antimicrobial activity some ethnomedicinal plants used by Paliyar tribe from Tamil Nadu, India. BMC complementary Altern. Med. 6, 35.

Essawi, T., Srour, M. 2000. Screening of some Palestinian medicinal plants for antibacterial activity. $J$. Ethanopharmacol. 46, 343-349.

Harborne, J. B., Williams, C. A.2001. Anthocyanins, other flavonoids. Nat prod. Rep. 18, 310 - 333.

Hollman, P.C., Katan, M. B. 1999. Health effects and bioavailability of dietary flavonols. Free Radi. Res. 31, 75-80.

Kinghorn, A.D., Balandrin, M.F.1993. Human medicinal agents from plants. American Chemical Society, San Francisco, USA.

Kokate, C.K., Purohit, A.P., Gokhale, S.B. 2006. Pharmacognosy. 34th ed. : Nirali Prakashan.

Kong, J.M., Goh, N.K., Chia, L.S., Chia,T. F. 2003. Recent advances in traditional plants drugs and orchids. Acta Pharmacologia Sci. 24,7-21.

Kumar, R., Sharma, R. J., Bairwa, K., Roy, R. K., Kumar, A. 2010. Pharmacological review on natural antidiarrhoel agents. Der Pharma Chemical. 2(2), 66-93.

Lesney, M.S. 2004. Nature's Pharmaceuticals: Natural Products from Plants Remain at the Core of Modern Medicinal Chemistry. TCAW. 13(7), 26-31.

Lin, K., Tierno, P.M., Komisar, A. 2004. Increasing antibiotic resistance of Streptococcus species in New York City. Laryngoscope, 114, 1147-1150.

Mahesh, C. M., Vidya, P. 2008. Isolation and Identification of Flavonoid "Quercetin" from Citrullus colocynthis (Linn.) Schrad.Plant Pathology Tissue Culture and Biotechnology 
Laboratory, Department of Botany,University of Rajasthan,Jaipur-302004; India.

Martinez-valverde, Periago, M.J. 2000. Unidad Docente de bromatologia .inspeccion de Alimentos, Faculted de veterinaria, Universidad de Murcia, Espana. Arch Latinoam nutr. 50(1), 518.

Newman, D.J., Cragg, G.M., Snader, K.M., 2003. Natural products as sources of newdrugs over the period 1981-2002. J. Natural Products. 66, 1022-1032.

Nair, R., Kalariya, T., Chanda, S. 2005. Antibacterial activity of some selected Indian medicinal flora. Turk. J. Biol. 29, 41-47.

Valsaraj, R., Pushpangadan, P., Smitt, U. W. 1997. Antimicrobial screening of selected medicinal plants from India.J. Ethnopharmacol. 58,75-83.

Verpoorte, R., Van der H., Memelink, J. 2000. Engineering the plant cell factory for secondary metabolite production. Transgenic Res. 9, 323343.

Newman, D.J., Cragg, G.M., Snader, K.M. 2003. Natural products as sources of newdrugs over the period 1981-2002. J. Natural Products. 66,1022-1032.

Okigbo, R. N., Igwe, M. 2007. The antimicrobial effects of Piper guineense uziza and Phyllantus amarus ebe-benizo on Candida albicans and Streptococcus faecalis. Acta Microbiol. Immunol. Hungarica. 54, 353-366.

Okigbo, R.N., Mmeka, E. C. 2006. An appraisal of phytomedicine in Africa. KMITL Sci. Tech. J. 6(2),83-94.

Panter 2008. Department of chemistry, university of Saskatchewan, 110 science place, S7N 5C9 Saskatoon, SK Canada.227(4),723-40.

Patel, D.K., Laloo, D., Kumar, R.,
Hemalatha, S., Pedalium, M.L. 2011. An overview of its phytopharmacological aspects. Asian Pac. J. Trop. Med. 4(9),748-755.

Patwardhan, B., Vaidhya, A.D.B., Chorghade, M. 2004. "Ayurveda and natural products drug discovery." Current Sci. 86, 789-799.

Razia, M., Karthiga, V., Lavanya, K., Deboral, P., Bernala, W. 2013. Department of Biotechnology, Mother Teresa Women's University, Kodaikanal-624101, Tamil Nadu. IJPBS.3(1),521-524.

Reena, S., Pramod, P., Khan, S.S. 2010. Screening for phytochemical analysis of Eucalyptus globulus Labill. and Emblica officinalis Gaertn. Nanobiotechnica Universale, 1(2), 103-106.

Padmavathy, S., Mekala, V. 2013. Preliminary Phytochemical Investigation of some Medicinal Plants of Western Ghats, The Nilgiris. Int. J. Res. in Pharmaceutical \& Biomed. Sci.4(1),

Sanjay, R.B., Bhagyashri, D. R. 2013. Extraction of some secondary metabolites \& thin layer chromatography from different parts of Centella asiatica L. (URB). American J. Life Sci. 1(6), 243-247.

Shariff, Z.U. 2001. Modern Herbal Therapy for Common Ailments. Nature Pharmacy Series, Vol. I. pp. $9-84$. Spectrum Books Limited, Ibadan, Nigeria in Association with Safari Books (Export) Limited, United Kingdom.

Sitara, U., Hassan, N., Naseem. J. 2011. Antifungal activity of Aloe vera gel against plant pathogenic fungi. Pak. $J$. Bot.43(4), 2231-2233.

Schinor, E.C., Salvador, M.J., Ito, I.Y., Dias, D.A. 2007. Evaluation of the antimicrobial activity of crude extracts 
and isolated constituents from

Chrestascapigera. Brazilian $J$.

Microbiol. 38, 145-149.

Satyavati, G.V., Gupta, A.K., Tandon, N.

1987. Medicinal plants of India, Indian

Council of Medical Research, New

Delhi, India.
U.K. 2010. Antihelmintic activity of Platycladus orientalis leaves extract. Int. J. Parasitology Res. 2(2), 1-3.

Zheng, W., Wang, S.Y. 2001. Antioxidant activity and phenolic compounds in selected herbs. J. Agri. Food Chem., 49(11), 5165-5170.

Sutar, N., Garai, R., Sharma, U. S., Sharma,

\section{How to cite this article:}

Vijaykumar Biradar. 2016. Extraction of Phytochemicals from Local Selected Plants and their Antibacterial Role. Int.J.Curr.Microbiol.App.Sci. 5(11): 707-720.

doi: http://dx.doi.org/10.20546/ijcmas.2016.511.082 